JPSCR: Journal of Pharmaceutical Science and Clinical Research, 2020, 02, 136-150

DOI: $10.20961 /$ jpscr.v5i2.39869

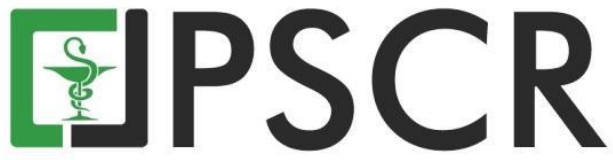

\title{
Formulasi dan Uji Efektivitas Daya Bersih Sabun Padat Kombinasi Arang Aktif Cangkang Sawit dan Sodium Lauril Sulfat
}

\author{
Uce Lestari $^{1^{*}}$, Syamsurizal ${ }^{2}$ dan Wulan Tri Handayani ${ }^{1}$ \\ ${ }^{1}$ Jurusan Farmasi, Fakultas Kedokteran dan Ilmu Kesehatan Universitas Jambi, Universitas Jambi, J1. Letjen \\ Suprapto, Jambi, Indonesia, 36361 \\ ${ }^{2}$ Program Studi Pendidikan Kimia, Fakultas Keguruan dan Ilmu Pendidikan, Universitas Jambi, Jl. Lintas \\ Sumatera, Jambi, Indonesia, 36122 \\ *email korespondensi: ucelestari@unja.ac.id
}

Received 12 Pebruary 2020, Accepted 17 October 2020, Published 30 October 2020

\begin{abstract}
Abstrak: Kemampuan sodium lauril sulfat (SLS) dalam membersihkan kotoran telah banyak dimanfaatkan sebagai bahan penunjang sediaan sabun padat, tetapi kombinasi dengan arang aktif cangkang sawit pemanfaatannya belum optimal untuk meningkatkan kemampuan dalam mengecilkan pori, membantu pengelupasan sel-sel kulit mati, mencerahkan kulit, dan menghilangkan noda hitam. Penelitian ini bertujuan untuk memformulasikan sabun padat kombinasi arang aktif cangkang sawit dengan SLS untuk meningkatkan efektivitas daya bersihnya. Desain penelitian yang digunakan adalah eksperimental dengan variasi konsentrasi arang aktif cangkang sawit dan SLS, yaitu 3:0, 2:1, 1:2, dan 0:3. Sabun padat dilakukan karakterisasi meliputi uji kadar air, alkali bebas, bahan tak larut etanol, dan kadar klorida dan stabilitas meliputi: organoleptis, $\mathrm{pH}$, tinggi busa, kekerasan berdasarkan Standar Nasional Indonesia (SNI). Data yang diperoleh dianalisis menggunakan statistik dengan taraf kepercayaan 95\%. Hasil uji sifat fisik dan stabilitas dari semua formula memenuhi SNI. Uji daya bersih dengan alat turbidimetri menunjukkan bahwa F2 paling efektif (64,8\% terhadap kontrol positif) dalam membersihkan noda dibandingkan dengan F4, F1, dan F3 secara berturut-turut. Formula dengan perbandingan arang cangkang sawit dan SLS 2:1 memiliki karakteristik fisiko kimia, stabilitas, dan daya bersih paling baik dibandingkan dari pada formula lainnya.
\end{abstract}

Kata kunci: Sabun padat; arang aktif; cangkang sawit; SLS

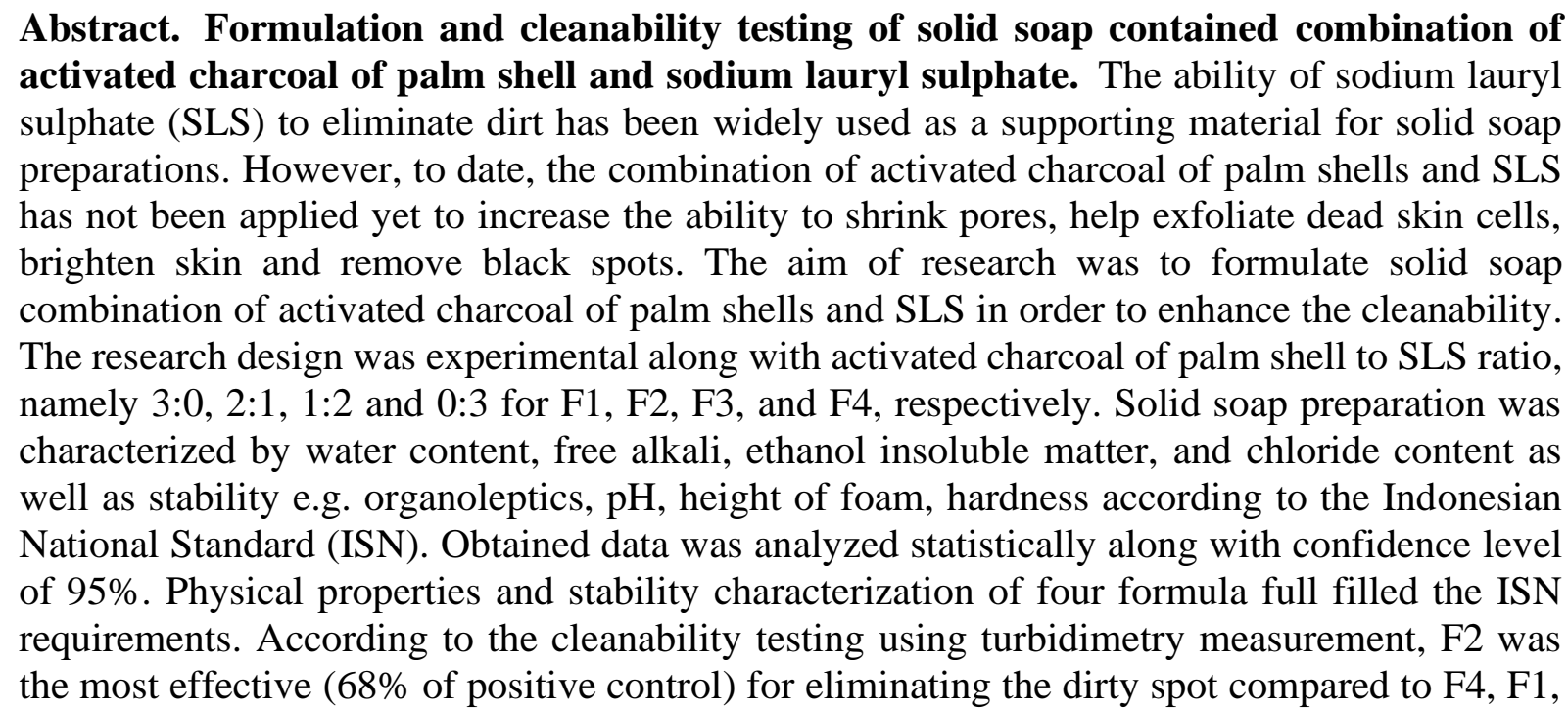


and F3, subsequently. Formulation along with activated charcoal of palm shell to SLS ratio of 2:1 had the best physicochemical characteristics, stability, and clenability among all formulations.

Keywords: Solid soap; activated charcoal; palm shell; SLS

\section{Pendahuluan}

Arang aktif merupakan suatu padatan berpori yang terbuat dari bahan yang mengandung karbon aktif berupa komponen senyawa organik. Kemampuan daya adsorpsinya yang tinggi telah banyak dimanfaatkan salah satunya sebagai bahan penunjang sediaan kosmetik, diantaranya adalah sebagai kosmetik pembersih yaitu sabun padat. Kandungan arang aktif di dalam sediaan sabun padat diketahui mampu mengecilkan pori, membantu pengelupasan selsel kulit mati sehingga mencerahkan kulit dan menghilangkan noda hitam (Shancez dkk., 2019).

Salah satu bahan baku yang memiliki kandungan karbon yang relatif tinggi serta dapat dimanfaatkan menjadi arang aktif adalah cangkang sawit. Arang aktif yang berasal dari cangkang sawit memiliki kualitas yang baik. Lestari dkk. (2019) melaporkan daya serap arang aktif cangkang sawit terhadap iodine dengan ukuran 200 mesh yang diaktivasi secara fisika pada suhu $600^{\circ} \mathrm{C}$ adalah sebesar $766,4 \mathrm{mg} / \mathrm{g}$. Nilai ini memenuhi syarat SNI No. 06-3730 yaitu minimal $750 \mathrm{mg} / \mathrm{g}$ dan lebih unggul dibandingkan dengan arang aktif lain seperti yang berasal dari tempurung kelapa dan kayu kelapa. Tempurung kelapa hanya sebesar 580 mg/g (Jamilatun dan Setyawan, 2014) dan kayu kelapa sebesar 544,2 - 665,1 mg/g (Polli, 2017). Daya adsorpsi arang aktif terhadap iodin merupakan parameter untuk menunjukkan kualitas daya serap arang aktif terhadap zat pengotor (Rumidatul, 2006). Selain itu, arang aktif cangkang sawit juga mengandung serat yang membantu mengangkat sel-sel kulit mati sehingga kulit menjadi lebih bersih (Khumaida, 2008).

Beberapa penelitian telah membuktikan bahwa arang aktif cangkang sawit mampu membersihkan dan mencerahkan, diantaranya dapat memutihkan gigi setelah diformulasikan kedalam sediaan pasta gigi (Syamsurizal dkk., 2019). Pada kosmetik kulit, sediaan lulur body $s c r u b$ arang aktif cangkang sawit membuat kulit panelis terlihat lebih bersih dan noda hitam memudar setelah pemakaian (Lestari dkk., 2017), serta pada sediaan masker gel peel off kombinasi PVA dan arang aktif cangkang sawit menunjukkan struktur permukaan kulit lebih halus dan bersih setelah pemakaian (Lestari dkk., 2019).

Hilirisasi produk inovasi berbahan dasar arang aktif cangkang sawit yang diolah menjadi produk kosmetik salah satunya adalah sabun padat. Dalam penelitian ini arang aktif cangkang sawit dikombinasikan dengan sodium lauril sulfat (SLS). Surfaktan ini merupakan bahan yang paling sering digunakan dalam sediaan sabun padat dan cukup baik ditoleransi oleh kulit (Barel 
dkk., 2009). SLS termasuk ke dalam surfaktan alkil yang sifatnya anionik, dapat menurunkan tegangan permukaan larutan berair dan digunakan sebagai lemak pengemulsi, bahan pembasah, dan deterjen (Löffer dan Happle, 2003).

Kombinasi arang aktif cangkang sawit dan SLS dengan berbagai variasi perbandingan belum pernah dilaporkan, dan diharapkan menghasilkan formula sabun padat yang memiliki sifat fisik (organoleptis, $\mathrm{pH}$, tinggi busa dan kekerasan) dan memiliki daya deterjensi yang baik. Selain itu, inovasi produk sabun padat ini membantu mengatasi limbah cangkang sawit dan meningkatkan daya gunanya sehingga bernilai ekonomis. Bahan yang digunakan dalam proses formulasi mudah didapat, biaya relatif murah, serta praktis dalam pembuatan. Penelitian ini bertujuan untuk memformulasikan dan memanfaatkan cangkang sawit yang diolah menjadi arang aktif dan diinkorporasikan dalam formula sabun.

\section{Bahan dan Metode}

\subsection{Bahan}

Arang aktif diproses dan diperoleh dari cangkang sawit (PT. Sumbertama Nusa Pertiwi Sungai Gelam; Jambi, Indonesia). Asam stearat, minyak kelapa, natrium hidroksida 15\%, SLS, gliserin merupakan bahan berderajat farmasi yang diperoleh dari supplier lokal Sari Kimia (Jambi, Indonesia). Etanol 96\% diperoleh dari Brataco (Jakarta, Indonesia) dan air.

\subsection{Metode}

\subsubsection{Pembuatan arang aktif cangkang sawit}

Cangkang sawit diperoleh dari limbah industri pengolahan kelapa sawit PT. Sumbertama Nusa Pertiwi Sungai Gelam (Jambi, Indonesia). Determinasi dilakukan di Laboratorium Herbarium, Universitas Andalas. Pembuatan arang aktif berdsarkan metode Sudrajat dkk. (1994) dalam Lestari dkk. (2017) dengan sedikit modifikasi. Cangkang sawit yang telah dikeringkan dipanaskan dalam furnace pada suhu $500^{\circ} \mathrm{C}$ (30 menit) pada proses karbonisasi hingga berubah menjadi arang. Arang dihaluskan menggunakan ball mill (Ball Mill model 2200x5500 menggunakan grinding media dengan kecepatan putaran $21 \mathrm{rpm}$ ), kemudian arang hasil milling disaring dengan ayakan 200 mesh untuk menyeragamkan ukuran partikel. Aktivasi arang secara fisika dilakukan dengan serbuk arang dipanaskan selama 2 jam menggunakan furnace pada suhu $600^{\circ} \mathrm{C}$ hingga menghasilkan arang aktif.

\subsubsection{Rancangan formula sabun padat arang aktif cangkang sawit}

Rancangan formula dibuat menjadi menjadi 4 formula dengan perbedaan rasio konsentrasi antara arang aktif cangkang sawit dan, penetapan variasi konsentrasi arang aktif cangkang sawit berdasarkan penelitian Febriyenti dkk., 2014 sedangkan konsentrasi SLS pada 
konsentrasi 1-3\%. Rancangan formula sabun padat arang aktif cangkang sawit dapat dilihat pada Tabel 1.

\subsubsection{Pembuatan Sabun Padat}

Pembuatan sabun padat dilakukan dengan metode hot process. Minyak kelapa sawit dipanaskan hingga suhu $70^{\circ} \mathrm{C}$ lalu dicampur dengan asam stearat dan ditambahkan $\mathrm{NaOH} 15 \%$ kemudian diaduk hingga homogen. Gliserin, gula pasir, dan SLS yang dilarutkan dengan air panas kemudian ditambahkan pada campuran tersebut. Campuran diaduk dengan mixer kecepatan 120 rpm dan ditambahkan etanol 96\% perlahan sampai campuran terlihat transparan. Campuran didinginkan dan dimasukkan serbuk arang aktif cangkang sawit dan parfum dan diaduk hingga homogen, kemudian dituangkan ke dalam cetakan sabun silikon, busa yang ikut tertuang dibersihkan secara manual. Campuran didiamkan selama 24 jam dan sabun dikeluarkan dari cetakan untuk dievaluasi.

Tabel 1. Rancangan formula sabun padat menggunakan kombinasi arang aktif cangkang sawit dan sodium lauril sulfat

\begin{tabular}{lcccc}
\hline \multirow{2}{*}{ Nama Bahan } & \multicolumn{4}{c}{ Formula (\%) } \\
\cline { 2 - 5 } & F1 & F2 & F3 & F4 \\
\hline Arang aktif cangkang sawit & 3 & 2 & 1 & 0 \\
Sodium lauril sulfat & 0 & 1 & 2 & 3 \\
Asam stearat & 10 & 10 & 10 & 10 \\
Minyak kelapa sawit & 25 & 25 & 25 & 25 \\
NaOH 15\% & 15 & 15 & 15 & 15 \\
Etanol 96\% & 20 & 20 & 20 & 20 \\
Gliserin & 20 & 20 & 20 & 20 \\
Gula pasir & 4 & 4 & 4 & 4 \\
Pewangi & 0,1 & 0,1 & 0,1 & 0,1 \\
Akuades ad & 100 & 100 & 100 & 100 \\
\hline
\end{tabular}

\subsubsection{Uji sifat fisik}

Uji sifat fisik dalam penelitian ini meliputi organoleptis, $\mathrm{pH}$, tinggi busa, kekerasan, dan daya pembasah. Pengukuran $\mathrm{pH}$ dilakukan menggunakan $\mathrm{pH}$ meter (Eutech; ThermoScietific, Waltham, MA) yang telah terkalibrasi. Sampel sebanyak $5 \mathrm{~g}$ dilarutkan dalam $10 \mathrm{~mL}$ air, kemudian dicelupkan elektroda ke dalam sampel dan dicatat nilai $\mathrm{pH}$ yang ditunjukkan $\mathrm{pH}$ meter (Sari dkk., 2010). Nilai pH untuk sabun mandi berkisar antara 9-11 (Hernani dkk., 2010).

Uji kemampuan busa sabun padat dilakukan terhadap air suling dan air sadah. Uji busa terhadap air suling dilakukan dengan melarutkan $1 \mathrm{~g}$ sampel menggunakan $50 \mathrm{~mL}$ air suling diukur tingginya menggunakan gelas ukur $1000 \mathrm{~mL}$. Sebanyak $200 \mathrm{~mL}$ larutan yang sama diteteskan melalui buret $50 \mathrm{ml}$ dengan ketinggian $90 \mathrm{~cm}$ di atas sabun. Tinggi busa yang 
terbentuk diukur setelah proses titrasi dan 5 menit setelahnya (Febriyenti dkk., 2014). Uji busa terhadap air sadah dilakukan dengan cara pembuatan air sadah yang mengandung $0,3 \mathrm{~g} \mathrm{CaCO}_{3}$ dan $0,15 \mathrm{~g} \mathrm{MgCO}_{3}$ dalam air suling $500 \mathrm{~mL}$ dengan penambahan beberapa tetes $\mathrm{HCl}$ agar terlarut sempurna. Kemudian pengujian dilakukan dengan Langkah yang sama pada uji busa terhadap air suling (Febriyenti dkk., 2014).

Uji kekerasan dilakukan menggunakan alat penetrometer (GY-3 dengan spesifikasi rentang pengukuran $0,5-12 \mathrm{~kg} / \mathrm{cm}^{2}$ dan resolusi pengukuran $0,1 \mathrm{~kg} / \mathrm{cm}^{2}$ ). Sediaan ditusuk menggunakan jarum pada alat dan dibiarkan menembus sediaan selama 5 detik pada suhu ruang $\left(27^{\circ} \mathrm{C}\right)$. Kekerasan dinyatakan dengan kedalaman penetrasi jarum ke dalam sediaan dinyatakan dalam 1/10 mm dari angka yang ditunjukkan pada skala penetrometer. Semakin tinggi kedalaman penetrasi jarum atau semakin besar skala menunjukkan bahwa sampel sabun semakin lunak (Hernani dkk., 2010).

Uji pembasah dilakukan menggunakan metode Draves yaitu benang kapas seberat $2 \mathrm{~g}$ dibuat gulungan sepanjang $9 \mathrm{~cm}$ dengan salah satu ujungnya diikatkan dengan beban seberat $500 \mathrm{mg}$. Sebanyak $100 \mathrm{mg}$ sampel dilarutkan dalam $1 \mathrm{~L}$ air dalam beaker gelas. Kemudian, benang dan beban dimasukkan ke dalam larutan sampel. Stopwacth dihidupkan mulai dari beban dijatuhkan hingga menyentuh dasar wadah. Persyaratan daya pembasah yaitu tidak lebih dari 30 detik (Febriyenti dkk., 2014).

Uji stabilitas menggunakan metode cycling test, satu siklus pengujian ini yaitu sebanyak $8 \mathrm{~g}$ sampel disimpan selama 24 jam pada suhu $4^{\circ} \mathrm{C}$ dan 24 jam selanjutnya pada suhu $40^{\circ} \mathrm{C}$. Uji stabilitas dilakukan dengan 6 siklus dan perubahan-perubahan yang terjadi diamati secara seksama (Butler, 2000).

\subsubsection{Uji efektivitas sediaan sabun padat}

Pengujian efektivitas sediaan sabut padat dilakukan secara kualitatif dan kuantitatif. Secara kualitatif, metode ini dilakukan dengan cara melarutkan $2 \mathrm{~g}$ sampel dalam $100 \mathrm{~mL}$ air dan dimasukkan ke dalam gelas beaker. Kemudian kertas saring dipotong sebanyak formula yang akan diuji dan ditetesi minyak (oli bekas) ke kertas saring dan dimasukkan ke dalam larutan sabun sampai terendam. Proses tersebut dilanjutkan dengan pengocokan kuat selama 1 menit, kemudian kertas saring diangkat dan dibilas dengan air (Warra dkk., 2010). Keefektifan daya pembersih dinilai secara visual berdasarkan minyak dan noda yang tertinggal dikertas saring dan dibandingkan dengan daya bersih sabun arang aktif komersil.

Secara kuantitatif pengujian ini dilakukan dengan cara mencelupkan kain yang telah diolesi dengan margarin sebagai kotoran yang mengandung minyak ke dalam larutan sabun. Kain diaduk kemudian diangkat dan tingkat kekeruhan air bilasan diasumsikan sebagai kotoran 
minyak yang dapat diangkat oleh sabun padat. Tingkat kekeruhan diukur menggunakan alat pengukur kekeruhan air yaitu turbidimeter dengan skala dinyatakan dalam nephelometric turbidity units (NTU).

\subsubsection{Uji fisiko kimia}

Uji fisiko kimia meliputi uji kadar air, alkali bebas, asam lemak bebas, lemak tak tersabunkan, kadar klorida, bahan tak larut etanol, dan total lemak. Uji ini dilakukan sesuai dengan yang tertera didalam SNI 3532-2016.

\subsubsection{Analisis Data}

Data pada penelitian ini dianalisis secara deskriptif dan dibandingkan dengan spesifikasi yang telah ditentukan pada acuan. Analisis evaluasi sifat fisik, uji fisiko-kimia dan uji efektivitas sediaan dilakukan secara statistik menggunakan metode analisis varian satu jalan (one-way ANOVA) dengan taraf kepercayaan 95\% dan jika ada perbedaan bermakna dilanjutkan dengan Duncan Test.

\section{Hasil dan Pembahasan}

Karakterisasi fisik sabun padat arang aktif cangkang sawit ditujukan untuk mengkarakterisasi mutu awal dari sediaan sabun padat arang aktif cangkang sawit. Tujuan dari karakterisasi ini adalah untuk mengevaluasi mutu secara fisik yang meliputi organoleptis, $\mathrm{pH}$, tinggi busa, kekerasan, uji pembahasan, dan uji efektivitas secara kualitatif dan kuantitatif. Hasil pemeriksanaan dapat dilihat pada Tabel 2.

Tabel 2. Hasil karakterisasi fisik dan efektivitas sabun padat arang aktif cangkang sawit.

\begin{tabular}{|c|c|c|c|c|c|}
\hline Kategori & F1 & F2 & F3 & F4 & Parameter \\
\hline Organoleptis & $\begin{array}{l}\text { Warna hitam } \\
\text { mengkilat, } \\
\text { aroma } \\
\text { greentea, } \\
\text { bentuk padat }\end{array}$ & $\begin{array}{l}\text { Warna hitam } \\
\text { mengkilat, } \\
\text { aroma } \\
\text { greentea, } \\
\text { bentuk padat }\end{array}$ & $\begin{array}{l}\text { Warna hitam } \\
\text { mengkilat, } \\
\text { aroma } \\
\text { greentea, } \\
\text { bentuk padat }\end{array}$ & $\begin{array}{l}\text { Warna } \\
\text { transparan, } \\
\text { aroma } \\
\text { greentea, } \\
\text { bentuk } \\
\text { padat }\end{array}$ & $\begin{array}{l}\text { Stabil tidak terjadi perubahan } \\
\text { warna, bau dan bentuk } \\
\text { sediaan (Depkes RI,1979). }\end{array}$ \\
\hline $\mathrm{pH}$ & 9,78 & 9,77 & 9,73 & 9,73 & $\begin{array}{l}\text { Nilai pH sabun padat adalah } \\
\text { 9-11 (BSN, 1996). }\end{array}$ \\
\hline Tinggi busa (cm) & 3,23 & 4,07 & 5,60 & 5,87 & $13-220 \mathrm{~mm}(\mathrm{SNI}, 1996)$ \\
\hline Kekerasan $\left(\mathrm{N} / \mathrm{cm}^{2}\right)$ & 22,06 & 21,90 & 18,89 & 16,85 & $\begin{array}{l}\text { Tidak ada standar kekerasan } \\
\text { sediaan sabun padat. }\end{array}$ \\
\hline $\begin{array}{l}\text { Uji } \\
\text { (detik) }\end{array}$ & 29,56 & 29,11 & 28,92 & 28,57 & $\begin{array}{l}\text { Daya pembasah sabun adalah } \\
\text { tidak lebih dari } 30 \text { detik } \\
\text { (Febriyenti dkk., 2014). }\end{array}$ \\
\hline $\begin{array}{l}\text { Uji efektivitas } \\
\text { secara kualitatif }\end{array}$ & Tidak Efektif & $\begin{array}{l}\text { Sangat } \\
\text { efektif }\end{array}$ & Tidak efektif & Efektif & $\begin{array}{l}\text { Semakin bersih kertas saring } \\
\text { nya maka semakin efektif } \\
\text { dalam membersihkan kotoran } \\
\text { dan lemak (SNI, 1996). }\end{array}$ \\
\hline $\begin{array}{ll}\text { Uji } & \text { efektivitas } \\
\text { secara } & \text { kuantitatif } \\
\text { (NTU) } & \end{array}$ & 211,33 & 250,67 & 187,33 & 239,00 & $\begin{array}{l}\text { Semakin tinggi nilai } \\
\text { kekeruhan menunjukkan } \\
\text { pengikatan kotoran dan lemak } \\
\text { lebih banyak (SNI,1996). }\end{array}$ \\
\hline
\end{tabular}




\subsection{Organoleptis}

Hasil menunjukkan bahwa tidak ada perbedaan dari segi aroma dan bentuk sediaan, tetapi berbeda warna antara F1, F2, dan F3 dengan F4. Pada F4 ditunjukan dengan warna transparan bening (Gambar 1). Hal ini dikarenakan tidak adanya penambahan arang aktif cangkang sawit, arang aktif memberikan kontribusi terhadap perubahan intentisatas warna dan penurunan konsentrasi arang aktif menunjukkan penurunan intensitas warna.

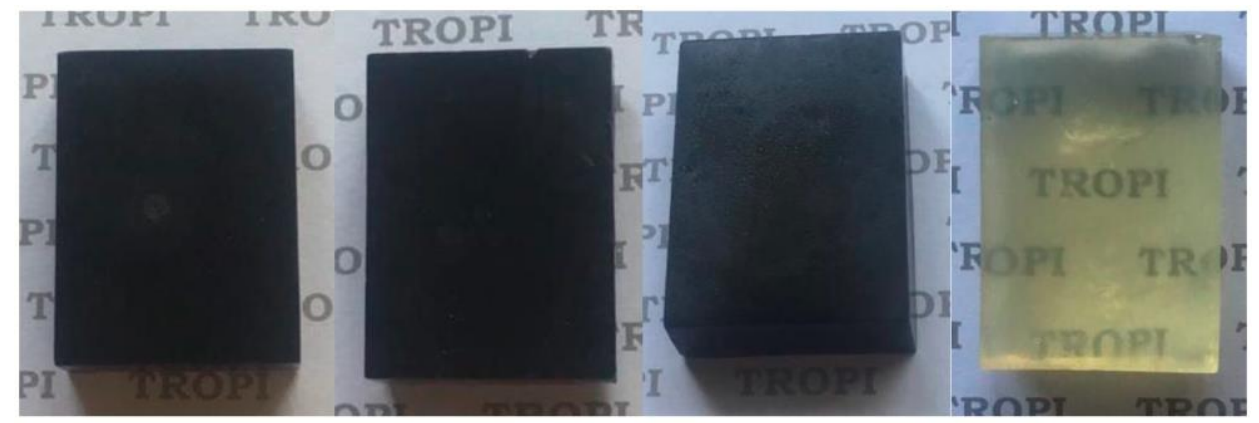

(a)

(b)

(c)

(d)

Gambar 1. Makroskopis sabun padat menggunakan variasi rasio arang aktif cangkang sawit dan sodium lauril sulfat menggunakan perbandingan 3:0 (a; F1), 2:1 (b, F2), 1:2 (c, F3), dan 3:0 (d, F4)

\subsection{Uji pH}

Nilai $\mathrm{pH}$ merupakan tolok ukur derajat keasaman dan merupakan salah satu indikator pada sediaan sabun (Wijana dkk., 2009). Sabun dengan $\mathrm{pH}$ yang relatif tinggi dapat meningkatkan daya absorpsi kulit sehingga kulit menjadi iritasi seperti mengelupas, gatal, luka, dan kulit menjadi kering (Sari, 2010). Hasil analisis menunjukkan bahwa variasi kombinasi arang aktif cangkang sawit dan SLS tidak memberikan pengaruh nyata terhadap nilai $\mathrm{pH}$ $(p>0,05)$. Nilai $\mathrm{pH}$ ini menunjukkan bahwa sediaan sabun yang dihasilkan bersifat basa yang sesuai dengan nilai persyaratan pH sediaan sabun yaitu 9-11 (BSN, 1996).

\subsection{Uji tinggi busa}

Salah satu parameter penting dalam menentukan mutu sabun adalah busa yang terbentuk. Variasi konsentrasi arang aktif cangkang sawit dan SLS berpengaruh nyata terhadap tinggi busa sabun padat arang aktif cangkang sawit $(p<0,05)$. Peningkatan konsentrasi SLS akan meningkatkan banyaknya bisa pada sediaan sabun karena SLS merupakan surfaktan aninonik yang berfungsi untuk meningkatkan busa, sedangkan arang aktif cangkang sawit tidak mempengaruhi timbulnya busa (Farn, 2006).

\subsection{Uji kekerasan}

Kekerasan sabun berperan dalam meningkatkan efisiensi sabun ketika digunakan. Hasil menunjukkan perbedaan nyata kombinasi konsentrasi arang aktif cangkang sawit dan SLS 
terhadap kekerasan sediaan $(p<0,05)$. Semakin meningkatnya konsentrasi arang aktif cangkang sawit, maka semakin meningkat kekerasan sabun. Hal ini disebabkan oleh penggunaan arang aktif cangkang sawit dalam bentuk serbuk sehingga meningkatkan kepadatan sediaan sabun yang dihasilkan. Kekerasan sabun padat ini juga dipengaruhi oleh penggunaan minyak sawit sebagai bahan utama. Sabun yang terbuat dari 100\% minyak sawit akan menghasilkan sabun yang bersifat keras karena kandungan asam palmitat didalamnya yang cukup besar (Butler, 2000). Asam palmitat, $\mathrm{CH}_{3}\left(\mathrm{CH}_{2}\right){ }_{14} \mathrm{COOH}$ memiliki sifat mengeraskan sabun dan menstabilkan busa (Butler, 2000). Sabun padat arang aktif cangkang sawit memiliki tingkat kekerasan lebih tinggi dibandingkan dengan sabun arang komersil yang menunjukkan bahwa sabun tidak mudah menyusut dan tahan lama untuk digunakan (Gusviputri dkk., 2013).

\subsection{Uji pembasah}

Hasil karakterisasi kemampuan pembasahan ditujukkan pada Tabel 2 bahwa waktu yang diperoleh cenderung semakin cepat dari F1, F2, F3, dan F4 karena perbedaan konsentrasi SLS dalam sediaan. SLS berfungsi sebagai bahan pembasah sehingga semakin meningkat konsentrasi SLS maka semakin cepat sabun menyerap ke dalam pori-pori (pembasah) (Löffer dan Happle, 2003). Hasil uji statistik menunjukkan bahwa kombinasi arang aktif cangkang sawit dan SLS tidak berpengaruh nyata terhadap daya pembasah sabun $(p>0,05)$. Nilai uji pembasah tiap formula ini memenuhi persyaratan daya pembasah yaitu tidak lebih dari 30 detik (Febriyenti dkk., 2014).

\subsection{Uji efektivitas sediaan sabun padat}

Uji secara kualitatif dilakukan untuk mengamati kemampuan sediaan sabun padat dalam mengangkat dan melarutkan kotoran minyak. Keefektifan daya bersih sabun secara kualitatif dinilai secara visual berdasarkan minyak dan noda yang tertinggal dikertas saring. Bahan minyak yang digunakan pada penelitian ini adalah oli motor bekas. Oli motor bekas memiliki kandungan minyak dan noda hitam. Hasil uji efektivitas secara kualitatif dapat dilihat pada Gambar 2.

Pada formula basis sabun menunjukkan sedikit hilangnya noda hitam dari oli akan tetapi masih meninggalkan kandungan minyak dari oli (tidak efektif). Pada formula F1 menunjukkan sedikit memucatkan warna kertas saring tetapi noda hitam masih tetap tertinggal (tidak efektif). Pada formula F2 menunjukkan warna sangat pucat menunjukkan noda hitam terangkat dengan sedikit minyak pada bagian tepi kertas saring (sangat efektif). Pada formula F3 menunjukkan masih tertinggalnya noda hitam pada kertas saring (tidak efektif). Pada formula F4 menunjukkan warna sangat pucat dengan sedikit noda hitam dibagian tepi kertas saring 
(efektif). Pada sabun pembanding menunjukkan kotoran berupa minyak terangkat akan tetapi noda hitam yang masih tertinggal pada kertas saring (kurang efektif).

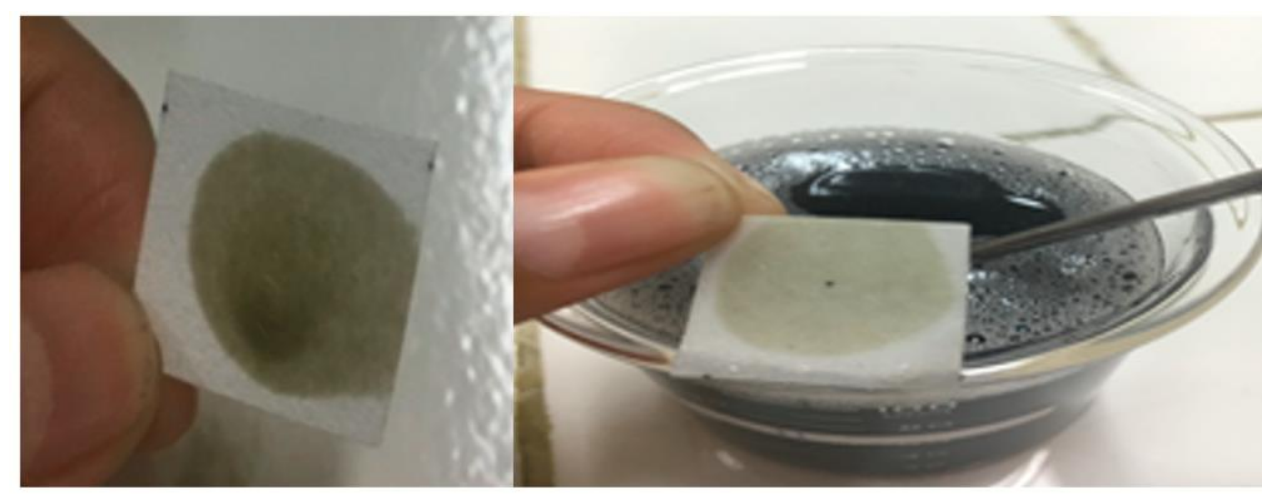

(a)

(b)

Gambar 2. Ilustrasi hasil uji daya bersih sabun padat menggunakan kombinasi arang aktif $2 \%$ dan sodium lauril sulfat $1 \%$ (F2) terhadap noda oli bekas sebelum pencucian (a) dan setelah pencucian (b)

Kotoran yang bersifat polar, dapat dihilangkan dengan pembilasan air, tetapi kotoran non polar seperti lemak membutuhkan surfaktan dalam menghilangkannya. Hal ini dikarenakan molekul sabun mempunyai rantai alkil yang relatif panjang yaitu $\mathrm{CH}_{3}\left(\mathrm{CH}_{2}\right)_{16}$ dan bersifat hidrofobik (tidak suka air), sedangkan bagian $\mathrm{COONa}^{+}$larut dalam air.

Arang aktif berperan dalam menyerap kotoran melalui proses adsorpsi. Adsorpsi merupakan suatu proses difusi zat-zat pada suatu permukaan atau antar partikel. Zat-zat yang terserap disebut adsorbat sedangkan bahan yang menyerapnya disebut adsorben (Warra dkk., 2010). Mekanisme proses adsorpsi oleh arang aktif terjadi melalui tiga tahap dasar, yaitu adsorbat berupa kotoran atau lemak terjarap pada bagian permukaan arang aktif yang kemudian berlanjut menuju ke dalam pori-pori arang dan akhirnya terjerap dibagian dinding-dinding pori bagian dalam arang aktif (Setyaningsih, 1995).

Kombinasi arang aktif cangkang sawit dan SLS di dalam sabun padat menunjukkan adanya efektivitas daya bersih sabun secara kualitatif dengan efektivitas paling baik ditunjukkan oleh formula F2. Hasil uji formula F2 ini juga menunjukkan hasil yang lebih baik dibandingkan dengan daya bersih dari sampel pembanding. Sabun padat arang aktif cangkang sawit tidak hanya membersihkan kotoran minyak saja melainkan mampu mengangkat noda hitam dari oli bekas, sedangkan pada uji sampel pembanding hanya menunjukkan kemampuan membersihkan minyak tanpa mengangkat noda hitam dari oli bekas. Daya bersih terhadap noda ini disebabkan oleh kandungan serat di dalam arang aktif cangkang sawit yang dapat menbantu mengangkat sel kulit mati, akibatnya noda yang menempel terangkat dari permukaan.

Uji kuantitatif dilakukan dengan mengukur tingkat kekeruhan pada air bilasan, semakin keruh air bilasan maka efektifitas pembersihan semakin tinggi dan sebaliknya. Hasil uji statistik 
menunjukkan kombinasi konsentrasi arang aktif cangkang sawit dan SLS memberikan pengaruh nyata terhadap keefektifan daya bersih sabun $(p<0,05)$. Nilai kekeruhan paling rendah terdapat pada basis sabun yaitu 127,33 NTU. Basis sabun ini tidak mengandung arang aktif maupun SLS di dalamnya sehingga kemampuan membersihkan kotoran hanya dilakukan oleh surfaktan yang terbentuk dari reaksi saponifikasi antara minyak kelapa sawit dan $\mathrm{NaOH}$.

Kombinasi penambahan arang aktif cangkang sawit dan SLS pada sabun menunjukkan adanya peningkatan efektivitas daya bersih sabun. Hasil uji turbidimeter menunjukkan bahwa tingkat kekeruhan yang paling mendekati nilai kekeruhan sampel pembanding (386,67 NTU) terdapat pada formula F2 dengan nilai 250,67 NTU. Beberapa hal yang dapat mempengaruhi daya bersih sabun arang aktif cangkang sawit terhadap kotoran minyak adalah kualitas bahan yang digunakan, kandungan asam lemak bebas dan teknik pembuatan sabun. Semakin bagus kualitas bahan dasar sabun maka semakin baik kemampuan deterjensinya, serta kandungan asam lemak bebas juga mempengaruhi nilai kekeruhan pada uji ini karena sabun yang mengandung asam lemak bebas akan menurunkan daya bersih sabun dan akan terikat pada molekul surfaktan (Qisti, 2009).

Tabel 3. Hasil karakterisasi formula sediaan sabun padat kombinasi arang aktif dan sodium lauril sulfat setelah uji stabilitas dipercepat.

\begin{tabular}{lllll}
\hline Kategori & F1 & F2 & F3 & F4 \\
\hline Organoleptis & Warna hitam & Warna hitam & Warna hitam & Warna \\
& mengkilat, & mengkilat, & mengkilat, & transparan \\
& aroma & aroma & aroma & bening, aroma \\
& greentea, & greentea, & greentea, & greentea, \\
& bentuk padat & bentuk padat & bentuk padat & bentuk padat \\
pH & 9,45 & 9,49 & 9,50 & 9,60 \\
Tinggi Busa $(\mathrm{cm})$ & 3,13 & 3,77 & 4,33 & 5,40 \\
Kekerasan $\left(\mathrm{N} / \mathrm{cm}^{2}\right)$ & 20,24 & 19,47 & 15,95 & 15,14 \\
Uji Pembasah (detik) & 28,44 & 28,39 & 28,35 & 28,04 \\
\hline
\end{tabular}

\subsection{Uji Stabilitas dipercepat}

Stabilitas menggambarkan perubahan suatu produk pada batas spesifikasi yang telah ditetapkan selama proses penyimpanan dan penggunaan untuk menjamin identitas, kekuatan, kualitas, dan kemurnian produk tersebut. Sediaan yang stabil adalah sediaan tidak berubah selama proses penyimpanan sampai akan digunakan. Hasil uji stabilitas organoleptis dapat dilihat pada Tabel 3 .

Hasil uji organoleptis pada metode cycling test pada sediaan sabun padat tidak menunjukkan adanya perbedaan antara sebelum dan sesudah uji. Tidak ada perubahan aroma greentea sebelum dan sesudah dilakukan cyling test pada sediaan, begitu juga dengan bentuk sediaan yaitu padat. Warna sabun sebelum dan sesudah dilakukan cycling test pada F1, F2, dan 
F3 adalah hitam dengan permukaan mengkilat, sedangkan pada F4 adalah berwarna bening transparan. Tidak adanya perubahan sebelum dan sesudah dilakukan cycling test menunjukkan bahwa sediaan sabun padat arang aktif cangkang sawit stabil selama penyimpanan.

Hasil uji stabilitas dipercepat yang tersaji pada Tabel 3 menunjukkan adanya penurunan nilai $\mathrm{pH}$ sesudah dilakukan cycling test. Terjadinya penurunan nilai $\mathrm{pH}$ dipengaruhi oleh perubahan suhu selama penyimpanan serta dapat terjadi akibat pengaruh adanya kontak sediaan dengan kelembaban udara, dimana gas $\mathrm{CO}_{2}$ di udara dapat bereaksi dengan air dalam sediaan sehingga membentuk asam. Terdapat perbedaan yang signifikan antara kombinasi arang aktif cangkang sawit dan SLS terhadap stabilitas penyimpanan sabun $(p<0,05)$. F4 berpengaruh nyata terhadap formula lainnya dengan nilai $\mathrm{pH}$ tertinggi yaitu 9,60. $\mathrm{pH}$ yang tinggi ini dipengaruhi oleh konsentrasi SLS yang tinggi dan SLS memiliki sifat asam. Meskipun mengalami penurunan nilai $\mathrm{pH}$ setelah dilakukan uji cycling test, sabun padat arang aktif cangkang sawit masih memenuhi persyaratan pH sabun sesuai BSN (1996) yaitu 9-11.

Hasil cycling test tinggi busa didapatkan rata-rata tinggi busa berkisar antara 3,13-5,40 $\mathrm{cm}$. Tinggi busa sabun cenderung naik seiring dengan meningkatnya konsentrasi SLS karena SLS merupakan bahan pembentuk busa yang baik (Barel dkk., 2009). Hasil uji setelah dilakukan cycling test menunjukkan terjadinya penurunan tingkat kekerasan pada semua formula. Tidak ada syarat dalam penilaian tingkat kekerasan sabun, untuk itu sabun pembanding digunakan sebagai acuan (sabun komersil). Analisis statistik menunjukkan bahwa lama waktu dan suhu penyimpanan berpengaruh nyata terhadap tingkat kekerasan sabun padat arang aktif cangkang sawit $(p<0,05)$. Hal ini berbeda dengan hasil penelitian yang dilakukan oleh Agustini dan Agustina (2017), sabun mengalami peningkatan kekerasan setelah dilakukan uji stabilitas akibat penguapan selama proses penyimpanan. Penguapan ini menyebabkan kadar air di dalam sabun menjadi berkurang sehingga sabun kehilangan kandungan air dan mengeras.

Terjadinya perubahan tingkat kekerasan sabun padat arang aktif cangkang sawit yang semakin menurun dapat berkaitan dengan jenis minyak yang digunakan. Minyak yang digunakan dalam sabun padat ini adalah minyak kelapa sawit yang berfungsi sebagai minyak goreng. Minyak goreng sawit diperoleh dari proses fraksinasi cair yang melibatkan kandungan olein didalam sawit. Priani dan Lukmayani (2010) menyatakan bahwa olein sawit bersifat cair pada suhu ruang sehingga selama proses penyimpanan, sabun mengalami penurunan tingkat kekerasan oleh suhu ekstrim.

Berdasarkan data yang diperoleh, cycling test daya pembasah sabun padat arang aktif cangkang sawit menunjukkan rentang waktu sebelum dan sesudah dilakukan uji adalah semakin menurun, artinya waktu yang dibutuhkan seikat benang mencapai dasar wadah semakin cepat. 
Larutan sabun padat arang aktif cangkang sawit setelah uji stabilitas lebih cepat meresap masuk ke dalam pori-pori kulit sehingga memudahkan molekul sabun mencapai kotoran didalamnya.

\subsection{Karakterisasi fisiko-kimia sabun padat}

Karakterisasi sabun padat kombinasi arang aktif dan SLS ini dilakukan pada formula 2. Pengujian fisiko-kimia dilakukan untuk menentukan mutu sabun padat arang aktif cangkang sawit sesuai dengan standar SNI No. 3532-2016. Hasil karakterisasi dapat dilihat pada Tabel 4.

Tabel 4. Hasil uji fisiko-kimia sabun padat kombinasi arang aktif cangkang sawit dan sodium lauril sulfat 2:1 (F2)

\begin{tabular}{lllc}
\hline No. & Karakteristik & Hasil Uji & Persyaratan \\
\hline 1. & Kadar air $(\%)$ & $1,158-1,297$ & $<15$ \\
2. & Alkali bebas (setara $\mathrm{NaOH})(\mathrm{mg} / \mathrm{g})$ & 0,00 & $<0,1$ \\
3. & Asam lemak bebas (setara asam oleat) $(\%)$ & 3,42 & $<2,5$ \\
4. & Bahan tak larut etanol $(\%)$ & 2,85 & $<5,0$ \\
5. & Kadar klorida $(\%)$ & 0,07 & $<0,1$ \\
6. & Lemak tidak tersabunkan $(\%)$ & 1,11 & $<0,5$ \\
7. & Total lemak $(\%)$ & 10,43 & $>65,0$ \\
\hline
\end{tabular}

Berdasarkan hasil pengujian yang tersaji pada table 4 sediaan sabun memiliki rentang nilai antara 1,158-1,297\%. Nilai kadar air ini menunjukkan bahwa sediaan sabun yang dihasilkan sesuai dengan nilai persyaratan kadar air sediaan sabun padat yang ditetapkan SNI 3532-2016 yaitu tidak lebih dari 15\%. Menurut Hambali dkk. (2005) semakin banyak air yang terkandung dalam sabun, maka sabun akan lebih mudah menyusut dan konsistensinya menurun sehingga cepat habis pada saat digunakan.

Alkali bebas merupakan alkali dalam sabun yang tidak terikat dengan asam lemak. Berdasarkan hasil uji kadar alkali bebas sabun padat arang aktif cangkang sawit didapat nilai sebesar $0,00 \%$. Hasil ini menunjukkan bahwa alkali di dalam sabun padat arang aktif cangkang sawit bereaksi seluruhnya dengan asam lemak. Kadar alkali didalam sabun adalah maksimal $0,1 \%$ untuk natrium, hal ini dikarenakan alkali dapat mengakibatkan iritasi pada kulit

Asam lemak bebas merupakan senyawa asam lemak yang tidak berikatan dengan senyawa alkali selama proses pembuatan sabun. Hal ini dapat disebabkan oleh banyaknya jumlah minyak yang digunakan atau konsentrasi dan jumlah alkali yang sedikit. Tingginya asam lemak bebas yang terdapat pada sabun akan mengurangi daya membersihkan sabun (Rowe dkk., 2009). Hasil uji asam lemak bebas sabun padat arang aktif cangkang sawit adalah sebesar 3,42\%. Hal ini menunjukkan bahwa kandungan asam lemak sabun melebihi nilai yang diisyaratkan SNI 3532-2016 yaitu sebesar maksimal 2,5\%, hal ini disebabkan minyak sawit murni sedikit mengandung asam stearat. 
Salah satu bahan lain yang tidak larut dengan etanol adalah asam lemak karena perbedaan kepolaran. Pengujian ini bertujuan untuk mengamati bahan atau zat yang dapat tertinggal pada kulit karena tidak larut dengan air (polar) pada proses pembilasan. Berdasarkan hasil uji yang telah dilakukan bahan tak larut etanol yang terkandung dalam sediaan sabun padat arang aktif cangkang sawit adalah sebesar 2,85\%, nilai ini memenuhi standar SNI 3532-2016 yaitu tidak lebih dari 5,0\%, sehingga saat dilakukan proses pembilasan semua kotoran dan lemak terangkut dan kulit menjadi lebih bersih.

Klorida merupakan salah satu anion yang mudah larut dalam air. Kadar klorida ini diperoleh dari air bilasan sabun. Ion klorida dalam air apabila dikonsumsi dapat merusak ginjal, merusak sistem pernafasan manusia dan hewan, serta bersifat korosif (Tranggono dan Latifah, 2013). Berdasarkan hasil uji kadar klorida sabun padat arang aktif cangkang sawit diperoleh nilai kadar klorida sebesar $0,07 \%$. Hal ini sesuai dengan standar yang telah ditentukan yaitu kadar klorida dalam sabun padat adalah maksimal 0,1\% (SNI, 2016) sehingga sabun padat arang aktif cangkang sawit aman untuk digunakan.

Lemak tak tersabunkan menunjukkan jumlah senyawa yang tidak tersabunkan yaitu senyawa yang tidak bereaksi atau tidak berikatan dengan alkali Natrium pada saat proses pembuatan sabun. Hasil uji lemak tak tersabunkan dari sabun padat arang aktif cangkang sawit adalah sebesar $1,11 \%$. Hal ini menunjukkan adanya kandungan lemak yang terdapat di dalam sabun yang tidak berikatan dengan alkali natrium didalamnya. Senyawa yang tidak tersabunkan ini berkaitan dengan zat-zat yang terkandung didalam minyak yang digunakan, biasanya berupa sterol dan hidrokarbon (Hernani dkk., 2010). Kelebihan asam lemak bebas ini dapat diatasi dengan meningkatkan konsentrasi alkali atau menambahkan jumlah alkali saat proses penyabunan.

Total lemak merupakan jumlah asam lemak pada sabun yang telah bereaksi maupun yang belum bereaksi dengan alkali. Sari (2010) menyatakan bahwa kandungan total lemak yang tinggi dapat menghasilkan sabun dengan sifat cenderung licin, lebih lembut dan juga lembab. Berdasarkan hasil uji total lemak yang telah dilakukan diperoleh nilai total lemak sebesar $10,43 \%$. Nilai total lemak ini belum sesuai dengan SNI sabun padat yaitu minimal $65 \%$. Hal ini juga terjadi pada penelitian Sihombing dkk., (2018) tentang sabun transparan buah papaya, nilai yang rendah kadar lemak total pada sabun disebabkan oleh bahan-bahan tambahan pada saat proses formulasi yaitu gula berfungsi membentuk struktur transparan pada sabun akibatnya jumlahnya menjadi lebih sedikit daripada sabun mandi padat biasa. Bahan pengisi yang dapat ditambahkan untuk meningkatkan jumlah total lemak pada sabun contohnya adalah madu, gliserol, waterglass, dan protein susu. Tujuan penambahan bahan pengisi ini adalah untuk 
membentuk kepadatan pada sabun, melembabkan serta menambah kandungan nutrisi yang diperlukan untuk kulit (Qisti, 2009).

\section{Kesimpulan}

Cangkang sawit dapat diformulasikan dalam sediaan sabun padat menggunakan kombinasi sodium lauril sulfat. Formula yang paling baik memenuhi persyaratan evaluasi sifat fisik, stabilitas pada penyimpanan dan efektivitas daya bersih terdapat pada formula F2 (arang aktif cangkang sawit 2\% dan SLS 1\%). Kombinasi arang aktif cangkang sawit dan SLS meningkatkan efektivitas daya bersih sabun. Uji kualitatif daya bersih sabun menunjukkan sabun padat arang aktif cangkang sawit lebih efektif mengangkat minyak dan noda hitam dibandingkan dengan sabun arang aktif komersil. Pada uji kuantitatif sabun padat arang aktif cangkang sawit 1,5 kali lebih jernih daripada sabun padat komersil.

\section{Ucapan Terima Kasih}

Peneliti mengucapkan kepada Universitas Jambi yang telah memberikan fasilitas alat dan laboratorium terkait penelitian ini.

\section{Deklarasi Konflik Kepentingan}

Semua penulis menyatakan tidak ada konflik kepentingan terhadap naskah ini.

\section{Daftar Pustaka}

Agustini, N. W. S dan Agustina, H. W. (2017). Karakteristik dan aktivitas antioksidan sabun padat transparan yang diperkaya dengan ekstrak kasar karotenoid chlorella pyrenoidosa. JPB Kelautan Dan Perikanan, 12(1): 1-12.

Barel, A.O., Paye, M., dan Maibach, H.I. (2009). Handbook of Cosmetics Science and Technology, 3rd Edition. Informa Healthcare USA, Inc, New York.

Badan Standarisasi Nasional. (1996). Standar Mutu Sabun Mandi, SNI 06-3532-1994, Dewan Standarisasi Nasional, Jakarta.

Butler, H. (2000). Poacher's Parfumes, Cosmetics and Soap, 10th Edition. Kluwer Academy Publisher, London.

Depkes RI. (1979). Farmakope Indonesia Edisi III. Depkes RI, Jakarta.

Farn R.J. (2006). Chemistry and Technology of Surfactants, Blackwell Publishing, Oxford.

Febriyenti, L. I. Sari., R. Nofita. (2014). Fomulasi sabun transparan minyak ylang-ylang dan uji efektivitas terhadap bakteri penyebab jerawat. Jurnal Sains Farmasi \& Klinis, 1(1): 61-71.

Gusviputri, A., P. N., Meliana, A., dan N. Indraswati. (2013). Pembuatan sabun dengan lidah buaya (Aloe vera) sebagai antiseptik alami. Widya Teknik, 12(1): 11-21.

Hambali, E. A, Suryani dan M. Rival. (2005). Membuat Sabun Transparan. Penebar Plus, Jakarta.

Hernani, T. K. Bunasor dan Ftriati. (2010). Formula sabun transparan anti jamur dengan bahan aktif ekstrak lengkuas (Alpinia Galanga L. Swartz). Buletin Litro, 21(2): 192-205.

Jamilatun, S., Setyawan, M. (2014). Pembuatan arang aktif dari tempurung kelapa dan aplikasinya untuk penjernihan asap cair. Spektrum Industri, 12(1): 74-83.

Khumaida. (2008). Kajian Proses Pembuatan Sabun Scrub Menggunakan Serat Oyong (Luffa acutangula) Kering. Skripsi, Institut Pertanian Bogor, Bandung.

Lestari, U., F. Farid dan P. M. Sari. (2017). Formulasi dan uji sifat fisik lulur body scrub arang 
aktif dari cangkang sawit (Elaeis guineensis Jacg.) sebagai detoksifikasi. Jurnal Sains Dan Teknologi Farmasi, 9(1): 74-79.

Lestari, U., F. Farid dan A. Fudholi. (2019). Formulation and effectivity test of deodorant from activated charcoal of palm shell as excessive sweat adsorbent on body. Asian Journal of Pharmaceutical and Clinical Research, 12(10): 193-196.

Löffer, H and R. Happle. (2003). Profile of irritant patch testing with detergents: sodium lauryl sulfate, sodium laureth sulfate and alkyl polyglucoside. Contact Dermatitis, 48(1): 2632.

Polii, F. F. (2017). Pengaruh suhu dan lama aktivasi terhadap mutu arang aktif dari kayu kelapa. Jurnal Industri Hasil Perkebunan, 12(2): 21-28.

Priani, S.E dan Y. Lukmayani. (2010). Pembuatan Sabun Transparan Berbahan Dasar Minyak Jelantah Serta Hasil Uji Iritasinya Pada Kelinci. Prosidings, Hal: 31-48.

Qisti, Rachmiaty. (2009). Sifat Kimia Sabun Transparan dengan Penambahan Madu pada Konsentrasi yang Berbeda. Skripsi, Bogor: IPB.

Rowe, R. C., Sheskey, P. J. and Quinn, M. E. (2009). Handbook of Pharmaceutical Excipients, 6th Edition, 53-54, RPS Publishing, UK.

Rumidatul, Alfi. (2006). Efektivitas Arang Aktif Sebagai Adsorber Pada Pengolahan Air Limbah. Bogor: Pascasarjana Institut Pertanian Bogor.

Shancez, N., R. Fayne, B. Burroway, B.W. (2019). Charcoal: an ancient material with a new face. Clinics in Dermatology, 38(2): 262-264.

Sari, T. Indah., J. P. Kasih, dan T. J. N. Sari. (2010). Pembuatan sabun padat dan sabun cair dari minyak jarak. Jurnal Teknik Kimia, 17(1): 28-33.

Setyaningsih, H. 1995. Pengolahan Limbah Batik Dalam Proses Kimia Dan Adsorpsi Karbon Aktif. Tesis, Universitas Indonesia, Jakarta.

Standar Nasional Indonesia. (1996). Arang Aktif Teknis, SNI 06-3730-1995. Badan Standarisasi Nasional, Jakarta.

Standar Nasional Indonesia. (2016). Standar Mutu Sabun Mandi Padat, SNI 3532-2016. Badan Standarisasi Nasional, Jakarta.

Syamsurizal., U. Lestari., Nurhasanah. (2019). Formulation of toothpaste activated charcoal from palm shell (Elaeis guineensis jacg) as teeth withening for nicotine addicts. International Journal of Pharmaceutical Sciences Review and Research, 58(2): 9-12.

Sihombing, Y. R., A. Syarifudin, R. Berutu. (2018). Formulasi sediaan sabun mandi padat dari ekstrak etanol buah mengkudu (Morinda Citrifolia L.) segar. Jurnal Penelitian Farmasi Herbal, 1(1): 22-24.

Tranggono, R. I dan Latifah, F. (2013). Buku Pegangan Ilmu Pengetahuan Kosmetik. PT Gramedia, Jakarta.

Warra, A. A., L. G. Hasan, S.Y. Gunu, S.A. Jega. (2010). Cold-process synthetis and properties of soaps prepared from different triacylglycerol sources. Nigerian Journal of Basic And Applied Science, 18(2): 315-321.

Wijana dan Muhammad Rohmadi. (2009). Analisis Wacana Pragmatik Kajian Teori dan Analisis. Surakarta: Yuma Pustaka.

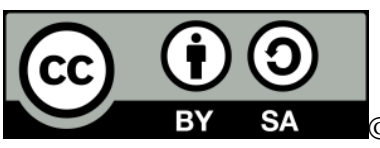

2020 by the authors. Submitted for possible open access publication under the terms and conditions of the Creative Commons Attribution-ShareAlike 4.0 International (CC BY-SA 4.0) license (https://creativecommons.org/licenses/by-sa/4.0/). 